PROFESI (Profesional Islam): Media Publikasi Penelitian

2019; Volume 16; No 2.

Website: ejournal.stikespku.ac.id

\title{
Pengaruh Pemberian Teh Rambut Jagung (Zea Mays L) Terhadap Kadar Gula Darah Penderita Diabetes Tipe 2
}

\author{
Nurul Hidayah ${ }^{1 *}$, Raudhotun Nisak ${ }^{2}$ \\ ${ }^{1,2}$ Prodi DIII Keperawatan/Akademi Keperawatan Pemerintah Kabupaten Ngawi \\ *Email: nurulridlo@gmail.com
}

\begin{abstract}
Kata Kunci
Teh Rambut

Jagung,

Flavonoid,

Diabetes

Mellitus

tipe 2.
\end{abstract}

Key Words:

Zea mays

Tea,

Flavonoids,

type 2

Diabetes

Mellitus.

\begin{abstract}
Abstrak
DM Tipe 2 masih menjadi masalah utama penyakit tidak menular. Hiperglikemia pada DM Tipe 2 yang disebabkan karena stress oksidatif diharapkan dapat diturunkan dengan pemberian flavonoid. Tujuan penelitian ini untuk membuktikan pengaruh pemberian teh rambut jagung terhadap kadar gula darah penderita DM tipe 2. Jenis penelitian eksperimen murni dengan rancangan time series dan teknik sampel menggunakan cluster sampling. Subjek penelitian adalah penderita DM tipe 2 sebanyak 60 orang yang dibagi menjadi 2 kelompok. Kelompok intervensi diberi teh rambut jagung selama 14 hari berturut-turut sedangkan kelompok kontrol tidak diberi teh rambut jagung. Kadar gula darah puasa diukur menggunakan spektrofotometri menggunakan darah vena, dan asupan makanan diukur menggunakan food recall 24 jam dan dianalisis menggunakan nutri survey. Analisis statistik menggunakan Uji-t dan regresi linier berganda. Hasil penelitian pada kelompok intervensi terdapat perbedaan kadar GDP penderita DM tipe 2 setelah diberikan teh rambut jagung dengan nilai-p 0,014, dan pada kelompok kontrol tidak terdapat perbedaan kadar GDP penderita DM tipe 2 setelah perlakuan dengan nilai-p 0,502. Analisis multivariat menunjukkan pengaruh usia, asupan dan gula darah puasa pre intervensi secara bersama terhadap gula darah puasa post sebesar 43,5\%. Kesimpulan terdapat perbedaan yang bermakna pada gula darah penderita DM Tipe 2 setelah diberikan teh rambut jagung.
\end{abstract}

\section{The effect of administering Zea mays Tea to Blood Sugar Levels for People with Type II Diabetes Mellitus}

\section{Abstract}

Type 2 Diabetes Mellitus (DM) is still a major problem of non-contagioud diseases. Hyperglycemia in Type 2 DM caused by oxidative stress is expected to be reduced by giving flavonoids. The purpose of this study was to prove the effect of giving Zea mays Tea on blood sugar levels of type 2 DM patients. The research type was true experimental research with time series design and the sampling technique used was cluster sampling. The research subjects were 60 people with type 2 diabetes mellitus who were divided into 2 groups. The intervention group was given Zea mays tea for 14 consecutive days while the control group was not given Zea mays tea. Fasting blood sugar levels were measured by using spectrophotometry using venous blood, and food intake was measured using 24-hour food recall and was analyzed using nutrient survey. Statistical analysis was conducted by using Kruskal Wallis and multiple linear regressions. The results of the intervention group showed that there were differences in the level of fasting blood sugar of type 2 DM patients after being given Zea mays tea with a P-value of 0.014, and in the control group there was no difference in the level of fasting blood sugar of type 2 DM patients after treatment with a P 0 value, 502. Multivariate analysis showed the influence of age, intake, and fasting blood sugar of pre intervention together to the post fasting blood sugar at 43.5\%. It could be concluded that there were significant differences in the blood sugar of patients with Type 2 DM after being given Zea mays Tea. 
PROFESI (Profesional Islam): Media Publikasi Penelitian 2019; Volume 16; No 2.

Website: ejournal.stikespku.ac.id

\section{PENDAHULUAN}

Prevalensi penyakit tidak menular tambah tahun semakin meningkat. Salah satu penyakit tidak menular adalah DM Tipe 2. Peningkatan prevalensi penyakit ini tidak hanya di negara maju, tetapi juga di negara-negara berkembang, salah satunya Indonesia. Data dari Global Report On Diabetes 2016 menyebutan sebanyak 422 juta penduduk di dunia menderita diabetes dan sebagian besar adalah DM Tipe 2 (WHO, 2016). WHO juga memprediksikan pada tahun 2030 DM akan menjadi salah satu dari kelompok 7 besar penyakit di dunia (WHO, 2014). Peningkatan prevalensi penyakit ini juga terjadi di Indonesia pada tahun 2013 sebesar 2,1\% dan di Jawa timur sebesar 2,6\% jika dibandingkan pada tahun 2007 (Kemenkes RI, 2013). Data dari Dinas Kesehatan Kabupaten Ngawi menyebutkan prevalensi penderita Diabetes Melitus (DM) tahun 2015 sebesar 934 kasus dan terus meningkat menjadi 1134 kasus tahun 2016. Data dari Januari sampai dengan Mei 2017 sebesar 1210 kasus dengan prevalensi tertinggi di UPT Puskesmas Paron sebesar 125 kasus. Hal ini menunjukkan adanya peningkatan prevalensi penyakit DM Tipr 2 yang mengkhawatirkan (Simpus, 2016).

Diabetes mellitus (DM) tipe 2 adalah suatu penyakit kronis progresif yang ditandai dengan ketidakmampuan tubuh melakukan metabolisme karbohidrat, lemak dan protein yang mengarah pada kondisi hiperglikemia (Black, 2014). Hiperglikemia pada DM tipe 2 disebabkan karena kelainan sekresi insulin, kelainan kerja insulin, atau kombinasi keduanya. Keluhan yang sering dialami penderita DM adalah polidipsi (banyak minum), polifagi (banyak makan) dan poliuri (Sering miksi). Penderita DM berisiko mengalami komplikasi seperti retinopati diabetes, neuropati diabetes, nefropati diabetes dan ulkus diabetes (Setiati et al., 2015).

Beberapa faktor penyebab DM tipe 2 adalah genetik, usia, jenis kelamin, asupan makanan, obesitas, aktivitas fisik dan stress (Black, 2014). Saat ini stess oksidatif sering dianggap sebagai pemicu munculnya penyakit kronis seperti DM. Pemberian antioksidan mampu mengurangi efek merusak dari stress oksidatif pada sel (Upritchard et al., 2000).

Seiring dengan meningkatnya prevalensi Diabetes tipe 2, maka semakin banyak pula upaya yang dilakukan untuk menurunkan prevalensi penyakit DM tipe 2 baik dari segi kuratif seperti pemakaian obat-obatan maupun dari segi preventif dengan pengaturan diet dan sumber pangan (Tjokroprawiro et al., 2015). Salah satu bahan pangan yang berpotensi mempunyai sifat fungsional makanan untuk mengontrol kadar gula darah pada penderita DM Tipe 2 adalah yang mengandung antioksidan. (Koloay et al., 2015). Rambut jagung merupakan salah satu bagian dari jagung yang sering tidak dimanfaatkan karena dianggap sebagai sampah. Salah satu kandungan gizi pada rambut jagung adalah flavonoid yang bersifat sebagai antioksidan (Guo, 2009). Antioksidan berfungsi melindungi tubuh dari radikal bebas (Kurniasih, 2013). Flavonoid bekerja dengan cara menstimulasi ambilan glukosa pada jaringan perifer, mengatur aktifitas dan ekspresi enzim yang terlibat pada jalur metabolisme karbohidrat dan bertindak menyerupai insulin dengan mempengaruhi insulin signalling sehingga berdampak pada penurunan gula darah puasa (Cazarolli et al., 2008). Flavonid juga memodulasi metabolisme lipid sehingga mengurangi komplikasi DM akibat abnormalitas profil lipid dan resistensi insulin (Zhao et al., 2007).

Studi manfaat teh rambut jagung untuk menurunkan kadar glukosa darah pada subjek manusia (khususnya penderita DM Tipe 2) belum pernah ada. Penelitian Putri (2016) menunjukkan rambut jagung 0,3 $\mathrm{g}$ yang dikeringkan bersaman dengan daun kelor 1,7 g kadar antioksidan tertinggi ketika dikeringka pada suhu $50^{\circ} \mathrm{c}$ sebesar $85,8 \%$. Hal berbeda ditunjukkan oleh penelitian Ismiati (2015), bahwa aktivitas antioksidan rambut jagung tertinggi didapatkan pada rambut jagung segar dibandingkan dengan yang dikeringkan, dengan lama perebusan kurang lebih 5 menit sebesar 59,404\%. Studi penelitian lain pernah dilakukan tentang efektifitas ekstrak rambut jagung terhadap penurunan kadar gula darah tikus putih jantan galur wistar yang diinduksi aloksan, hasilnya ekstrak rambut jagung memiliki efek menurunkan kadar gula darah dan dosis yang paling efektif ialah $2,52 \mathrm{~g} / \mathrm{KgBB}$ (Koloay et al., 2015). Dari beberapa penelitian terdahulu membuktikan rambut jagung berpotensi menurunkan kadar glukosa darah pada tikus wistar, akan tetapi penelitian tersebut belum dapat membuktikan efektivitas rambut jagung untuk menurunkan glukosa darah puasa pada manusia yang penderita DM tipe 2. Berdasarkan latar 
PROFESI (Profesional Islam): Media Publikasi Penelitian

2019; Volume 16; No 2.

Website: ejournal.stikespku.ac.id

belakang diatas peneliti tertarik untuk melakukan studi lebih lanjut tentang pengaruh pemberian teh rambut jagung (Zea mays $L$ ) terhadap kadar gula darah penderita DM Tipe 2 di wilayah kerja Puskesmas Paron Kabupaten Ngawi.

\section{METODE PENELITIAN}

Jenis penelitian ini true experimental dengan desain penelitian time series design. Penelitian ini dilakukan bulan Maret-September 2018. Tempat penelitian wilayah kerja Puskesmas Paron Kabupaten Ngawi. Jumlah populasi 162. Pengambilan sampel dilakukan dengan cluster sampling, jumlah sampel 30. Kriteria inklusi: Kadar glukosa Darah Puasa: 126-600 mg/dl, IMT $\geq 18,5-22,9 \mathrm{~kg} / \mathrm{m} 2$ (Normal), Usia 40-65 tahun, belum pernah menggunakan teh rambut jagung sebagai terapi diabetes melitus tipe 2, minum obat jenis glibenklamid dan metformin. Kriteria eksklusi: Penderita DM tipe II dengan terapi insulin, mengundurkan diri, atau meninggal dunia, atau pindah domisili ke Kecamatan lain saat penelitian berlangsung. Apabila individu memenuhi kriteri dan bersedia menandatangani informed concent, selanjutnya ditetapkan sebagai subjek penelitian.

Penelitian ini terdiri dari 3 tahap, yaitu tahap persiapan penelitian, tahap pelaksanaan penelitian dan tahap analisis data. Tahap persiapan terdiri dari: proses persiapan bahan baku penelitian, meliputi pembelian rambut jagung di petani dan pengeringan serta analisis kadar vlafonoid rambut jagung di laboratorium pangan dan gizi UGM. Selain itu dilakukan uji hedonitas, dan etichal clearance di RS Moewardi Solo. Pada tahap ini juga dipersiapan instrumen penelitian berupa chack list. Tahap pelaksanaan terdiri dari 3 tahap, yaitu: Penentuan subjek penelitian sesuai kriteria inklusi; Randomisasi untuk menentukan kelompok intervensi dan kontrol; dan pemberian perlakuan pada kelompok intervensi dan kontrol.

Pada kelompok intervensi: diberikan teh rambut jagung seberat $150 \mathrm{~g}$ yang telah dikeringkan pada suhu 50 0c, kemudian direbus pada 300 $\mathrm{ml}$ air mendidih selama 5 menit, kemudian disaring tanpa ditambah gula, dan diminum selama 14 hari berturut-turut setiap pagi didepan peneliti. Obat oral diabetes tetap dikonsumsi selama penelitian. Kelompok kontrol tidak diberikan minum teh rambut jagung. Obat oral diabetes tetap dikonsumsi selama penelitian. Asupan makan pada kedua kelompok dikaji menggunakan food recall $24 \mathrm{jm} 1$ kali selama penelitian dan dianalisis menggunakan nutriasurvey. Pengukuran kadar gula darah pada kelompok intervensi dan kontrol menggunakan darah vena sebanyak $1 \mathrm{cc}$, kemudian dicentrifuge, dan serum darah diinterpretasikan berdasarkan Gula darah puasa. Alat yang diperlukan spektrofotometer, spuit $3 \mathrm{cc}$, alkohol swab, dan torniquet. Kondisi hiperglikemia jika kadar gula darah puasa: $>126 \mathrm{mg} / \mathrm{dl}$ (Setiati et al., 2015). Kadar gula darah puasa diukur sebanyak 3 kali dengan distribusi pengukuran diawal sebelum intervensi, pengukuran ke 2 pada hari ke 7 intervensi dan pengukuran ke 3 di akhir intervensi (hr ke 14). Analisis penelitian terdiri dari analisin univariat, bivariat dan multivariat. Analisis Univariat untuk mendeskripsikan karakteristik masing-masing variabel yang diteliti. Analisis Bivariat menggunakan uji Kolmogorov-Smirnov $Z$, dan uji beda Uji Kruskal-Wallis. Analisis multivariat menggunakan regresi linier berganda.

Variabel Independen penelitian ini adalah pengaruh pemberian teh rambut jagung Variabel Dependen pada penelitian adalah Kadar gula darah penderita DM Tipe 2 Variabel Confounding penelitian ini usia, Jenis Kelamin, Penyakit penyerta, Asupan Makanan, Obesitas, Stress.

\section{HASIL DAN PEMBAHASAN}

3.1 Karakteristik Subjek Penelitian

Karakteristik subjek penelitian ini meliputi: usia, jenis kelamin, pendidikan, pekerjaan, dan penyakit penyerta disajikan pada Tabel 1 .

Karakteristik responden berdasarkan usia pada kelompok intervensi sebagian besar berusia 56-60 tahun sebesar 12(40\%), sedangkan pada kelompok kontrol berusia 56-60 tahun dan 61-65 tahun sebesar 10 (33,3\%). Pada kelompok intervensi sebagian besar berjenis kelamin perempuan sebesar 21 (70\%), dan kelompok kontrol berjenis kelamin perempuan sebesar 20 $(66,6 \%)$. Berdasarkan tingkat pendidikan sebagian besar responden kelompok intervensi pendidikan terakhirnya SD sebesar 15 (50\%), dan kelompok kontrol 16 (53,3\%). Pekerjaan responden kelompok intervensi sebagian besar adalah petani $16(53,3 \%)$, dan kelompok kontrol 
PROFESI (Profesional Islam): Media Publikasi Penelitian 2019; Volume 16; No 2.

Website: ejournal.stikespku.ac.id

$13(43,3 \%)$. Berdasarkan komplikasi terbanyak yang diderita pada kelompok intervensi adalah hipertensi sebesar $12(43,3 \%)$, dan kelompok kontrol juga hipertensi sebesar (17 (56,7\%).

Tabel 1. Karakteristik subjek penelitian

\begin{tabular}{|c|c|c|c|c|c|c|}
\hline \multirow{3}{*}{ Karakteristik } & \multicolumn{4}{|c|}{ Kelompok penelitian } & \multirow{2}{*}{\multicolumn{2}{|c|}{ Total }} \\
\hline & \multicolumn{2}{|c|}{ Intervensi } & \multicolumn{2}{|c|}{ Kontrol } & & \\
\hline & $\mathrm{n}=30$ & $\%$ & $\mathrm{n}=30$ & $\%$ & $\mathrm{n}=60$ & $\%$ \\
\hline \multicolumn{7}{|l|}{ Usia (Tahun) } \\
\hline $40-45$ & 0 & 0 & 0 & 0 & 0 & 0 \\
\hline $46-50$ & 4 & 13,3 & 5 & 16,6 & 9 & 15 \\
\hline $51-55$ & 5 & 16,6 & 5 & 16,6 & 10 & 16,6 \\
\hline $56-60$ & 12 & 40 & 10 & 33,3 & 22 & 36,6 \\
\hline $61-65$ & 9 & 30 & 10 & 33,3 & 19 & 31,6 \\
\hline \multicolumn{7}{|l|}{ Jenis kelamin } \\
\hline Laki-laki & 9 & 30 & 10 & 33,3 & 19 & 31,6 \\
\hline Perempuan & 21 & 70 & 20 & 66,6 & 41 & 68,3 \\
\hline \multicolumn{7}{|l|}{ Pendidikan } \\
\hline $\mathrm{SD}$ & 15 & 50 & 16 & 53,3 & 31 & 51,6 \\
\hline SMP & 13 & 43,3 & 12 & 40 & 25 & 41,6 \\
\hline SMA & 1 & 3,33 & 2 & 6,66 & 3 & 5 \\
\hline Perguruan tinggi & 1 & 3,33 & 0 & 0 & 1 & 1,6 \\
\hline \multicolumn{7}{|l|}{ Pekerjaan } \\
\hline Petani & 16 & 53,3 & 13 & 43,3 & 29 & 48,3 \\
\hline Pedagang & 0 & 0 & 0 & 0 & 0 & 0 \\
\hline PNS & 0 & 0 & 0 & 0 & 0 & 0 \\
\hline IRT & 13 & 43,3 & 17 & 56,6 & 30 & 50 \\
\hline Pensiunan & 1 & 3,33 & 0 & 0 & 1 & 1,7 \\
\hline \multicolumn{7}{|l|}{ Penyakit penyerta } \\
\hline Hipertensi & 12 & 43,3 & 17 & 56,7 & 29 & 48,3 \\
\hline Kesemutan/ kebas & 5 & 16,7 & 7 & 23,3 & 12 & 20 \\
\hline $\begin{array}{l}\text { Gangguan } \\
\text { penglihatan }\end{array}$ & 7 & 23,3 & 4 & 13,3 & 11 & 18,3 \\
\hline Kolesterol & 6 & 20 & 2 & 6,7 & 8 & 13,3 \\
\hline
\end{tabular}

3.2 Data tentang status gizi responden penelitian yang dapat dilihat dari IMT (indek massa tubuh) dan asupan harian berdasarkan food recoll 24 jam dapat dilihat pada tabel 2 .

Tabel 2 Status Gizi Dan Asupan Harian

\begin{tabular}{|c|c|c|c|c|c|c|}
\hline \multirow{3}{*}{ Karakteristik } & \multicolumn{4}{|c|}{ Kelompok penelitian } & \multirow{2}{*}{\multicolumn{2}{|c|}{ Total }} \\
\hline & \multicolumn{2}{|c|}{ Intervensi } & \multicolumn{2}{|c|}{ Kontrol } & & \\
\hline & $n=30$ & $\%$ & $\mathrm{n}=30$ & $\%$ & $n=60$ & $\%$ \\
\hline IMT & & & & & & \\
\hline Laki-laki & & & & & & \\
\hline Normal & 9 & 30 & 10 & 33,3 & 19 & 31,7 \\
\hline Perempuan & & & & & & \\
\hline $\begin{array}{l}\text { Normal } \\
\text { Asupan Energi }\end{array}$ & 21 & 70 & 20 & 66,7 & 41 & 68,3 \\
\hline $\begin{array}{l}\text { Sesuai AKG } \\
\text { (2013) }\end{array}$ & 2 & 6,7 & 1 & 3,3 & 3 & 5 \\
\hline
\end{tabular}

\begin{tabular}{|c|c|c|c|c|c|c|}
\hline \multicolumn{7}{|l|}{$\begin{array}{l}\text { 1700-2100Kkal } \\
\text { Tidak sesuai AKG } \\
\text { (2013): }\end{array}$} \\
\hline$>2100 \mathrm{Kkal}$ & 1 & 3,3 & 0 & 0 & 1 & 1,7 \\
\hline$<1700$ & 27 & 90 & 29 & 96,7 & 56 & 93,3 \\
\hline \multicolumn{7}{|l|}{ Asupan Protein } \\
\hline $\begin{array}{l}\text { Sesuai AKG (2013) } \\
55,5 \mathrm{~g}-60 \mathrm{~g}\end{array}$ & 2 & 6,7 & 0 & 0 & 2 & 3,3 \\
\hline \multicolumn{7}{|l|}{$\begin{array}{l}\text { Tidak sesuai AKG } \\
\text { (2013): }\end{array}$} \\
\hline$>60 \mathrm{~g}$ & 1 & 3,3 & 0 & 0 & 1 & 1,7 \\
\hline$<55,5 \mathrm{~g}$ & 27 & 90 & 30 & 100 & 57 & 95 \\
\hline \multicolumn{7}{|l|}{ Asupan } \\
\hline $\begin{array}{l}\text { Sesuai AKG (2013) } \\
275 \mathrm{~g}-319 \mathrm{~g}\end{array}$ & 0 & 0 & 0 & 0 & 0 & 0 \\
\hline \multicolumn{7}{|l|}{$\begin{array}{l}\text { Tidak sesuai AKG } \\
\text { (2013): }\end{array}$} \\
\hline$>319 \mathrm{~g}$ & 1 & 3,3 & 0 & 0 & 1 & 1,7 \\
\hline$<275 \mathrm{~g}$ & 29 & 96,7 & 30 & 100 & 59 & 98,3 \\
\hline \multicolumn{7}{|l|}{ Asupan lemak } \\
\hline Sesuai AKG (2013) & 4 & 13,3 & 6 & 20 & 10 & 16,7 \\
\hline \multicolumn{7}{|l|}{$36.6 \mathrm{~g}-53 \mathrm{~g}$} \\
\hline \multicolumn{7}{|l|}{$\begin{array}{l}\text { Tidak sesuai AKG } \\
\text { (2013): }\end{array}$} \\
\hline$>53 \mathrm{~g}$ & 2 & 6,7 & 0 & 0 & 2 & 3,3 \\
\hline$<36,6 \mathrm{~g}$ & 24 & 80 & 24 & 80 & 48 & 80 \\
\hline $\begin{array}{l}\text { Pola makan tinggi } \\
\text { karbohidrat }\end{array}$ & 8 & 32 & 10 & 40 & 18 & 36 \\
\hline $\begin{array}{l}\text { Pola makan tinggi } \\
\text { lemak }\end{array}$ & 25 & 100 & 24 & 96 & 49 & 98 \\
\hline $\begin{array}{l}\text { Pola makan tinggi } \\
\text { kolesterol }\end{array}$ & 0 & 0 & 3 & 12 & 3 & 6 \\
\hline $\begin{array}{l}\text { Pola makan } \\
\text { rendah serat }\end{array}$ & 25 & 100 & 25 & 100 & 50 & 100 \\
\hline
\end{tabular}

\subsection{Uji hedonitas}

Uji hedonitas (daya terima) dilakukan pada penderita DM tipe 2 sebanyak 30 orang yang tinggal di puskesmas Paron dan dilakukan secara acak. Datar nama penderita DM tipe 2 diperoleh dari Simpus Puskesmas tahun 2017. Penderita DM tipe 2 diminta mencoba 2 teh rambut jagung yang berbeda dalam proses membuatnya dan diminta menentukan teh mana yang lebih disukai. Unsur yang dinilai adalah rasa, aroma dan warna, dari teh. Uji daya terima dapat dilihat pada tabel berikut: 
PROFESI (Profesional Islam): Media Publikasi Penelitian 2019; Volume 16; No 2.

Website: ejournal.stikespku.ac.id

Tabel 3 Uji Daya Terima Jus Tomat

\begin{tabular}{|c|c|c|c|c|c|c|}
\hline \multirow[b]{2}{*}{$\begin{array}{c}\text { Teh rambut } \\
\text { jagung }\end{array}$} & \multicolumn{4}{|c|}{ Uji Daya Terima Jus } & \multirow[b]{2}{*}{ Jumlah } & \multirow[b]{2}{*}{$\%$} \\
\hline & Suka & $\%$ & $\begin{array}{l}\text { Tidak } \\
\text { Suka }\end{array}$ & $\%$ & & \\
\hline Kode * & 5 & 16,6 & 2 & 6,7 & 30 & $100 \%$ \\
\hline Kode ** & 23 & 76,6 & 1 & 3,3 & 30 & $100 \%$ \\
\hline Kode $* * *$ & 2 & & 27 & 90 & & \\
\hline
\end{tabular}

\section{Keterangan:}

a. kode * adalah teh rambut jagung dari $100 \mathrm{~g}$ rambut jagung kering setelah dipanaskan pada suhu 500c dan direbus dalam $300 \mathrm{ml}$ air selama 5 menit kemudian disaring, tanpa diberi gula.

b. kode ** adalah teh rambut jagung dari $150 \mathrm{~g}$ rambut jagung kering setelah dipanaskan pada suhu 500c dan direbus dalam $300 \mathrm{ml}$ air selama 5 menit kemudian disaring, tanpa diberi gula.

c. kode $* * *$ adalah teh rambut jagung dari $200 \mathrm{~g}$ rambut jagung kering setelah dipanaskan pada suhu 500c dan direbus dalam $300 \mathrm{ml}$ air selama 5 menit kemudian disaring, tanpa diberi gula.

Dari tabel diatas dapat diketahui bahwa sebagian besar responden lebih menyukai teh rambut jagung dengan dosis pemberian $150 \mathrm{~g}$ karena rasanya tidak teh tidak pahit, aroma khas rambut jagung terasa, dan warnanya cukup tidak terlalu pekat.

Uji kandungan flavonoid dilakukan untuk mengetahui kandungan flavonoid pada teh rambut jagung. Pemeriksaan ini dilakukan di laboratorium pangan dan gizi UGM. Hasil pemeriksaan tersaji pada tabel 4

Tabel 4. Hasil uji falvonoid

\begin{tabular}{lcc}
\hline \multirow{2}{*}{ Kode sampel } & \multicolumn{2}{c}{ Hasil analisis } \\
\cline { 2 - 3 } & flavonoid $/ 100 \mathrm{~g}$ & Rata-rata \\
\hline $40^{\circ}$ c 3 hari & 204,09 & 204,22 \\
& 205,35 & \\
$50^{\circ}$ c 3 hari & 217,87 & 219,44 \\
& 221,01 & \\
\hline
\end{tabular}

Dari tabel diatas diketahui perbedaan suhu pengeringan untuk rambut jagung berpengaruh pada kadar flavonoid. Kandungan flavonoid pada pemanasan $50^{\circ} \mathrm{c}$ sebesar 219 lebih tinggi dibandingkan dengan suhu $40^{\circ} \mathrm{c}$. sebesar 204, sehingga yang dipakai pada penelitian ini rambut jagung dikeringkan pada suhu $50^{\circ} \mathrm{c}$

\subsection{Hasil Analisis Univariat}

Teh tambut jagung diberikan dengan tujuan kadar gula darah seorang penderita DM tipe 2 menurun. Distribusi frekuensi Kadar gula darah penderita DM tipe 2 pada kelompok intervensi sebelum diberikan teh rambut jagung sebesar $194,17 \pm 69,25 \mathrm{mg} / \mathrm{dl}$, dan setelah diberikan teh rambut jagung sebesar 136,53 $\pm 48,88 \mathrm{mg} / \mathrm{dl}$, sehingga terdapat penurunan kadar gula darah sebesar 58g/dl. Kadar gula darah penderita DM tipe 2 pada kelompok kontrol sebesar 195,13 \pm $81,09 \mathrm{mg} / \mathrm{dl}$ dan diakhir penelitian sebesar $209,30 \pm 88,67 \mathrm{mg} / \mathrm{dl}$.

\subsection{Hasil Analisis Bivariat}

a. Uji normalitas data dengan uji KolmogorovSmirnov $Z$ diperoleh hasil data tidak berdistribusi normal, dimana nilai signifikan < 0,05 , sehingga untuk uji beda dilanjutkan dengan menggunakan Kruskal Wallis.

b. Perbedaan Kadar Gula Darah Sebelum dan Setelah Pemberian teh rambut jagung pada kelompok Intervensi

Pengukuran ini dimaksudkan untuk mengetahui perbedaan kadar gula darah sebelum dan setelah diberikan teh rambut jagung kelompok intervensi

Perbandingan rerata skor kadar gula darah dengan menggunakan uji Kruskal Wallis. Hasil analisis bivariat tersaji pada Tabel 5:

Tabel 5. Hasil Analisis Bivariat Pengaruh Pemberian teh rambut jagung Terhadap Kadar

Gula Darah Pada Kelompok Intervensi

\begin{tabular}{lllcccc}
\hline Minggu & N & Mean & $\begin{array}{c}\text { Std } \\
\text { deviation }\end{array}$ & $\begin{array}{c}\text { Mini- } \\
\text { mum }\end{array}$ & $\begin{array}{c}\text { Maxsi- } \\
\text { mum }\end{array}$ & $\begin{array}{c}\text { Asymp } \\
\text { Sign }\end{array}$ \\
\hline $\begin{array}{l}\text { GDP pre } \\
\text { interven }\end{array}$ & 30 & 177,9 & 71,66 & 90 & 363 & .014 \\
si & & 3 & & & & \\
GDP & 30 & & & & & \\
Minggu & & & & & & \\
ke 1 & & & & & & \\
Gdp & 30 & & & & & \\
minggu & & & & & & \\
ke 2 & & & & & & \\
\hline
\end{tabular}

Dari tabel diatas didapatkan data rata-rata GDP sebelum perlakuan, diakhir minggu pertama dan diakhir minggu ke dua sebesar 177,93. Perhitungan statistik pada Kruskal Wallis didapatkan nilai GDP 8,53, df 2 dan nilai-p 0,014 $(<0,05)$, sehingga dapat disimpulkan bahwa terdapat perbedaan kadar GDP penderita DM tipe 2 setelah diberikan teh rambut jagung. 
b. Perbedaan Kadar Gula Darah Sebelum dan Setelah pada Kelompok Kontrol

Pengukuran ini dimaksudkan untuk mengetahui perbedaan kadar gula darah sebelum dan setelah penelitian pada kelompok kontrol. Perbandingan rerata skor kadar gula darah tersaji pada Tabel 6.

Tabel 6. Hasil Analisis Bivariat Kadar Gula Darah Pada Kelompok Kontrol

\begin{tabular}{lcccccc}
\hline \multicolumn{1}{c}{ Minggu } & \multirow{n}{*}{$\mathrm{n}$} & Mean & $\begin{array}{c}\text { Std } \\
\text { deviation }\end{array}$ & $\begin{array}{c}\text { Mini } \\
\text { mum }\end{array}$ & $\begin{array}{c}\text { Maxsi } \\
\text { mum }\end{array}$ & $\begin{array}{c}\text { Asymp } \\
\text { Sign }\end{array}$ \\
\hline $\begin{array}{l}\text { GDP pre } \\
\text { intervensi }\end{array}$ & 30199,52 & 81,24 & 102 & 411 & .502 \\
$\begin{array}{l}\text { GDP Ming- } \\
\text { gu ke 1 }\end{array}$ & & & & & \\
$\begin{array}{l}\text { Gdp ming- } \\
\text { gu ke 2 }\end{array}$ & & & & & \\
\hline
\end{tabular}

Dari tabel diatas didapatkan data rata-rata GDP sebelum, diakhir minggu pertama dan diakhir minggu kedua sebesar 199,52g/dl. Perhitungan statistik pada Kruskal Wallis didapatkan nilai GDP 1,380 dengan nilai-p 0, $502(>0,05)$ dan df 2 , sehingga dapat disimpulkan bahwa tidak terdapat perbedaan kadar GDP penderita DM tipe 2 sebelum dan setelah pada kelompok kontrol

\subsection{Hasil Analisis Multivariat}

Analisis multivariat menggunakan regresi linear berganda dan dilakukan pada kedua kelompok baik kelompok intervensi maupun kelompok kontrol. Hasil analisis regresi linear berganda, faktor-faktor yang mempengaruhi Kadar Gula Darah puasa penderita DM tipe 2 dapat dilihat pada Tabel 7 berikut ini:

Tabel 7. Hasil Analisis Multivariat, FaktorFaktor yang Mempengaruhi Kadar Gula Darah Puasa Setelah Diberikan Perlakuan pada Penderita DM Tipe 2

\begin{tabular}{lrrrrrrrr}
\hline & & \multirow{2}{*}{ Variabel } & $\mathrm{B}$ & $\mathrm{N}$ & & \multicolumn{2}{c}{ Regretion } & \multicolumn{2}{c}{ CI 95\% } \\
\cline { 6 - 8 } \cline { 5 - 8 } & & $\mathrm{p}$ & & $\mathrm{f}$ & $\begin{array}{c}\text { Nilai } \\
\mathrm{p}\end{array}$ & bawah & Atas \\
\hline Constanta & 259,07 & 0,00 & 2,982 & & & 80,47 & 437,67 \\
Usia & $-3,233$ & 0,02 & $-2,379$ & & & $-6,02$ &,- 43 \\
Asupan &,- 164 & 0,55 &,- 601 & & &,- 725 & 0,39 \\
GDP pre & 0.37 & 0,00 & 3.583 & & & 0,16 & 0,58 \\
intervensi & & & & & & & \\
Regresion & & & & 6,681 & 0,02 & & \\
R & 0,66 & & & & & & \\
$\mathrm{R}^{2}$ & 0.43 & & & & & & \\
\hline
\end{tabular}

Sumber: Data Primer (2018)
Dari tabel 7 untuk uji $\mathrm{t}$ tabel diketahui nilai signifikan untuk pengaruh usia terhadap kadar gula darah puasa post intervensi sebesar $0,02<0,05$, dan nilai $\mathrm{t}$ hitung $-2,379<2,05$ ( $\mathrm{t}$ tabel), sehingga dapat disimpulkan terdapat pengaruh usia terhadap kadargula darah puasa. Nilai signifikan asupan terhadap kadar gula darah puasa sebesar 0,55>0,05, dan nilai t hitung -,725 $<$ tabel $(2,056)$, sehingga dapat disimpulkan $\mathrm{H} 2$ ditolak yang berarti tidak terdapat pengaruh asupan terhadap kadar gula darah. Nilai signifikan GDP pre intervensi terhadap kadar gula darah puasa sebesar $0,00<0,05$, dan nilai t hitung $3,583>t$ tabel $(2,056)$, sehingga dapat disimpulkan $\mathrm{H} 3$ diterima yang berarti ada pengaruh kadar gula darah pre intervensi terhada kadar gula darah post intervensi. Untuk uji $\mathrm{F}$ berdasarkan out put data diketahui nilai sinifikan untuk pengaruh usia, asupan dan gdp pre intervensi secara bersama-sama terhadap gula darah puasa post intervensi sebesar $0,002<0,005$, dan F hitung $6,681>\mathrm{f}$ tabel $(2,96)$, sehingga dapat disimpulkan bahwa ada pengaruh usia, asupan dan gdp pre intervensi secara simultan terhadap gdp post intervensi. Berdasarkan outpt diatas diketahui nilai $\mathrm{R}$ square sebesar 0,435 , hal ini mengandung arti bahwa pengaruh variabel usia, asupan dan gdp pre intervensi secara bersama terhadap gdp post sebesar $43,5 \%$

\section{PEMBAHASAN}

Hasil penelitian ini menunjukkan ada perbedaan kadar gula darah puasa penderita DM tipe 2 pada kelompok intervensi sebelum dan setelah diberikan teh rambut jagung sebanyak $150 \mathrm{~g}$ yang telah dikeringkan pada suhu $55^{\circ} \mathrm{c}$, kemudian direbus selama 5 menit dan diminum secara rutin selama 14 hari berturut-turut. Hal ini sesuai dengan penelitian Koloay et al., (2015), yang menyatakan bahwa rambut jagung berpotensi menurunkan kadar gula darah pada tikus putih jantan galur wistar (Rattus norvegicus L.) yang diinduksi aloksan sebesar $130 \mathrm{mg} / \mathrm{KgBB}$ secara intraperitoneal, dengan efektivitas dosis sesesar 2,52 g/KgBB yang diminum selama 14 hari berturut-turut. Pada penelitian ini rambut jagung dikeringkan pada suhu $55^{\circ} \mathrm{c}$ dan diperoleh kadar flavonoid sebesar 219 tiap100 g rambut jagung kering. Pada pelaksanaan penelitian 
PROFESI (Profesional Islam): Media Publikasi Penelitian

2019; Volume 16; No 2.

Website: ejournal.stikespku.ac.id

diberikan rambut jagung $150 \mathrm{~g}$ dengan kadar flavonoid sebesar 329. Proses pengeringan rambut jagung dilakukan merujuk pada penelitian Putri (2016), yang menyatakan rambut jagung sebanyak $0,3 \mathrm{~g}$ yang dikeringkan bersama daun kelor sebanyak 1,7 g kadar antioksidan tertinggi diperoleh pada pemanasan suhu 550c sebesar $85,8 \%$. Rambut jagung (Zea mays L.) mengandung senyawa flavonoid yang berfungsi untuk merangsang pengaktifan insulin sehingga menurunkan kadar gula darah. Flavonoid sebagai antioksidan eksogen tubuh dapat merangsang perbaikan sel-sel yang rusak di dalam tubuh dengan menstabilkan radikal bebas juga melengkapi kekurangan elektron yang dimiliki radikal bebas yang dapat menimbulkan stress oksidatif. Berkurangnya stress oksidatif dapat mengurangi terjadinya resistensi insulin terhadap gula sehingga mencegah perkembangan disfungsi sel $\beta$ pankreas (Kolay et al., 2015). Flavonoid bekerja dengan cara memperbaiki toleransi glukosa dengan menstimuli pengambilan glukosa pada jaringan perifer, mengatur aktivitas dan ekspresi enzim yang terlibat dalam jalur metabolisme karbohidrat dan bertindak menyerupai insulin, dengan mempengaruhi mekanisme insulin signalling sehingga berdampak pada penurunan kadar GDP (Cazarolli et al., 2008). Flavonoid juga dapat memodulasi metabolisme lipid, glukosa, memperbaiki resistensi insulin perifer dan mengurangi komplikasi DM yang disebabkan oleh abnormalitas profil lipid dan resistensi insulin (Zhao et al., 2007).

Hasil analisis multivariat menunjukkan bahwa usia, asupan dan kadar gula darah puasa sebelum perlakuan secara simultan berpengaruh terhadap kadar gula darah puasa setelah perlakuan sebesar $43,5 \%$. Pada penelitian ini sebagian besar responden berusia 56-65 tahun. Prevalensi DM tipe 2 terus meningkat pada usia lanjut, hal ini disebabkan karena perubahan anatomi, fisiologi dan biokimia dari tingkat sel, jaringan dan organ yang mempengaruhi fungsi homeostasis tubuh akibat dari proses menua. Salah satu organ yang mengalami perubahan adalah sel $\beta$ pankreas penghasil insulin, sel-sel jaringan target yang menghasilkan glukosa, sistem syaraf, dan hormon lain yang mempengaruhi kadar glukosa darah (Bilous dan Donelly, 2015). Prevalensi DM Tipe 2 terus meningkat pada usia 45 tahun Wicaksono (2011), dan terbanyak pada usia 51-60 tahun (Awad et al., 2011). Semakin bertambahnya usia, menjadikan lansia kurang aktif, sehinga berat badan bertambah, massa otot berkurang dan akibat proses menua terjadi penyusutan sel-sel beta yang progresif (D'adamo, 2008).

Pada penelitian ini prevalensi DM tipe 2 pada responden wanita lebih banyak dibandingkan dengan pria, hal ini disebabkan karena komposisi lemak tubuh wanita lebih banyak dibandingkan dengan pria, sehingga wanita lebih mudah gemuk dan berisiko menderita DM Tipe 2 (Silverthorn, 2014). Timbunan lemak bebas dalam darah peningkatan up-take sel terhadap asam lemak bebas dan memacu oksidasi lemak yang pada akhirnya menghambat penggunaan glukosa dalam otot (Wright, 2008). Penelitian di RS King Abdulaziz juga menunjukkan prevalensi DM Tipe2 56\% nya adalah wanita dan $70 \%$ berusia 18-59 tahun (Alsulaiman et al., 2016).

Asupan energi, karbohidrat, lemak dan protein secara simultan berpengaruh terhadap kadar gula darah penderita DM tipe 2. Pada Penelitian ini sebagian besar asupan energi protein, karbohidrat dan lemak pada kedua kelompok termasuk dalam kategori kurang dari AKG (2013), meskipun demikian pada pola konsumsi harian responden berdasarkan hasil recall terdapat kecenderungan mengkonsumsi asupan tinggi karbohidrat, tinggi lemak, dan rendah serat. Pada penelitian ini diketahui IMT responden termasuk dalam kategori normal dengan rerata pemenuhan energi harian sebesar $1.218 \mathrm{Kkal}$, sedangkan kebutuhan energi untuk IMT Normal pada penderita DM tipe 2 sebesar 1700-2100 Kkal, sehingga dapat dikatakan asupan energi responden kurang dari kebutuhan (Man et al., 2014). Pengaturan asupan makanan menjadi salah satu pilar tatalaksanan DM Tipe 2, sehingga penderita DM Tipe 2 dianjurkan untuk makan menu seimbang sesuai kebutuhan kalori masing-masing untuk mencegah terjadinya hiperglikemia dan hipoglikemia (Ri, 2012; Tjokroprawiro et al., 2015).

Berdasarkan hasil recall yang dilakukan selama 1 kali pada kedua kelompok menunjukkan asupan karbohidrat responden berasal dari nasi, umbi-umbian, roti manis, mie dan minuman 
seperti teh, kopi dan susu. Asupan karbohidrat berdasarkan nilai AKG (2013) sebagian besar adalah kurang, meskipun demikian ditemukan kecenderungan pola konsumsi karbohidrat berlebih, seperti: mengkonsumsi nasi bersamaan dengan makanan penukar nasi (mie, umbiumbian, roti) dalam waktu yang bersamaan. Pembatasan asupan karbohidrat dilakukan responden berdasarkan informasi yang diperoleh pada saat pencairian pengobatan. Pola konsumsi responden berisiko mengakibatkan hiperglikemia, hal ini sesuai dengan pendapat Man et al, (2014) yang mengatakan pola konsumsi makanan dengan indeks glikemik tinggi tetapi rendah serat berisiko meningkatkan kadar glukosa darah. Jenis asupan karbohidrat yang dianjurkan pada penderita DM tipe 2 adalah untuk dikonsumsi adalah: sereal yang berasal dari padi-padian, tanaman polong, buah-buahan utuh, dan sayuran (Mann et al., 2014; Rafanani, 2013).

Asupan lemak sebagian besar responden termasuk kategori kurang, meskipun demikian terdapat kecenderungan pola konsumsi tinggi lemak. Sebagian besar responden mengkonsumsi gorengan sebagai lauk makan ataupun kudapan, seperti: tahu, tempe, telur, kerupuk, pisang, pastel, singkong, tumis sayur dan santan. Pada DM Tipe 2 asupan lemak tak jenuh tunggal (MUFA) dapat diberikan antara $10-20 \%$ dari total energi, dan PUFA sebesar 10\% dari total energi. Kedua asam lemak ini berfungsi menurunkan kadar LDL darah, tetapi konsumsi yang berlebihan akan merangsang oksidasi lipid yang berlebih sehingga menimbulkan penurunan HDL dan meningkatkan kadar glukosa darah. Pada penderita DM dianjurkan mengolah makanan menggunakan sedikit minyak seperti dipanggang, dikukus, dibuat sup, atau direbus.

Data recall tentang asupan serat menunjukkan seluruh responden kurang mengonsumsi serat harian dari yang dianjurkan yaitu $40 \mathrm{gr} / \mathrm{hr}$ atau 20gr/1000 Kkal per hari. Sebagian besar menu makanan yang dikonsumsi jarang dilengkapi dengan sayur-mayur dan buah. Makanan yang kaya serat dan dapat larut berfungsi memperbaiki kontrol glikemik dan profil lipid penderita DM tipe 2. Penyajian sayur atau buah yang kaya serat sebanyak lima kali atau lebih setiap hari, dan penyajian tanaman polong sebanyak empat kali atau lebih perminggu dapat membantu kebutuhan minimum akan serat (Man et al., 2014).

Asupan protein responden pada penelitian ini berdasarkan AKG (2013) termasuk kategori kurang, Hasil recall sebagian besar asupan protein berasal dari protein nabati seperti: tahu, tempe, ikan air tawar, daging ayam dan hewan berkaki empat. Protein adalah zat gizi yang penting untuk pertumbuhan dan berfungsi mengganti jaringan tubuh yang rusak, sehingga asupan protein diperlukan setiap hari. Asupan protein dapat diberikan antara $10-20 \%$ dari total asupan energi atau sesuai dengan 0-8-2.0 gr/ $/ \mathrm{kg}$ $\mathrm{BB} /$ hari pada DM tanpa komplikasi penyakit ginjal. Pembatasan asupan protein maksimal $0.8 \mathrm{gr} / \mathrm{KgBB} /$ hari dilakukan pada penderita $\mathrm{DM}$ dengan komplikasi gagal ginjal karena akan memperberat kerja ginjal. Sumber protein banyak terdapat dalam ikan, ayam, daging, tahu, tempe dan kacang-kacangan (Mann et a.l, 2014).

Pada penderita DM berisiko mengalami komplikasi mikro maupun makrovaskuler. Beberapa komplikasi penyakit yang diderita responden meliputi hipertensi, kebas/kesemutan, gangguan penglihatan dan kolesterol. Hal ini sesuai dengan penelitian Sosale et al., (2016) penderita DM tipe 2 beresiko mengalami gangguan penglihatan, system syaraf, gagal ginjal, penyakit jantung dan strok. Jika sudah ada komplikasi upaya mengontrol kadar gula darah dan penyakit akan lebih sulit. Keterbatasan penelitian ini, adalah: tidak diamatinya tingkat stress pada responden sehingga tidak dapat menjelaskan pengaruh negatif stress terhadap kadar glukosa darah pada penderita DM tipe 2 yang diberikan teh rambut jagung.

\section{SIMPULAN}

a. Teh rambut jagung sebanyak $150 \mathrm{~g}$ yang dikeringkan pada suhu $50^{\circ} \mathrm{C}$ dan direbus dengan air sebanyak $300 \mathrm{ml}$ selama 5 menit dan diminum secara teratur selama 14 hari berturut-turut dapat menurunkan kadar gula darah pada responden sebanyak $58 \mathrm{~g} / \mathrm{dl}$.

b. Hasil penelitian ini dapat membuktikan teori fungtional food dalam penurunan kadar gula darah puasa penderita DM tipe 2 
PROFESI (Profesional Islam): Media Publikasi Penelitian 2019; Volume 16; No 2.

Website: ejournal.stikespku.ac.id

c. Teh rambut jagung dapat dijadikan terapi pendukung dalam penurunan kadar gula darah puasa penderita DM tipe 2

\section{UCAPAN TERIMAKASIH}

Ucapan terimakasih kami sampaikan kepada Kementrian Riset, Teknologi, dan Pendidikan Tinggi Republik Indonesia yang telah membiayai penelitian ini. Dinas Kesehatan Kabupaten Ngawi, LPPM Akper Pemkab Ngawi yang telah memfasilitasi pelaksanaan penelitian.

\section{REFERENSI}

Alsulaiman, Al-Ajmi, Al-Qahtani, Fadlallah, Nawar, Shukerallah, Nadeem, Al-Weheedy, Hassan, Shahin, Kolib. (2016). Control of type 2 diabetes in King Abdulaziz Housing City (Iskan) population, Saudi Arabia. J Family Community Med. 23(1): 1-5. Doi: $\underline{10.4103 / 2230-8229.172221}$

Awad, N., Langi, Y.A., Pandelaki, K. (2011). Gambaran faktor resiko pasien Diabates Melitus Tipe 2 di poliklinik endokrin bagian/SMF UNSTRAT RSU Prof DR. R.D Kandou Manado Periode Mei-Oktober 2001. Skripsi. Fakultas Kedokteran: Universitas Sam Ratulangi Manado. Journal e-Biomedik Tersedia dalam: http://ejournal.unsrat.ac.id/index.php/ebio medik/article/view/1160

Bilous, R. dan Donelly, R. (2015). Buku Pegangan Diabetes. Ed 4. Jakarta: Bumi Medika.

Black, J.M. dan Hawks, J.H. (2014). Keperawatan Medikal Bedah: Manajemen Klinis Untuk Hasil Yang Diharapkan. Jakarta: EGC

Cazarolli LH, Zanatta L, Alberton EH, Fiqueiredo MS, Folador P, Damazio RG, Pizzolatti MG, Silva FR. (2008). Flavonoid: Cellular and Molecular Mechanism of Action in Glucose Homeostasis. Mini Rev Med Chem. 8(10):1032-8.
D'adamo, Peter, J. (2008). Diet Sehat Diabetes sesuai Golongan Darah. Yogyakarta: Delapratasa.

Guo, J., Liu, T., Han, L. \& Liu, Y. (2009). The Effects of Corn Silk on Glycaemic Metabolism. Nutrition \& Metabolism. 6:47.

Ismiati, E.R. (2015). Aktivitas antioksidan minuman herbal rambut jagung dengan varian kondisi dan lama perebusan. Skripsi. Universitas Muhammadiyah Surakarta

Kemenkes RI. (2013). Riset Kesehatan Dasar. Diakses 14 Oktober 2015. http://www. depkes.go.id/resources/download/general/ Hasil\%20Riskesdas\%202013.pdf

Kolay, K., Citraningtyas,G., Lolo,W.A. (2015). Uji efektivitas ekstrak etanol rambut jagung (Zea mays L) Terhadap penurunan kadar gula darah tikus putih jantan wistar (ratus norvegicus L) yang diinduksi aloksan. Manado. Jurnal Ilmiah Farmasi.4 (3) ISSN $2302-2493$

Kurniasih. (2013). Khasiat Dan Manfaat Daun Kelor Untuk Penyembuhan Berbagai Penyakit. Yogyakarta: Pustaka Baru Press.

Mann, J., Truswell, A.S. (2014). Buku Ajar Ilmu Gizi. Jakarta: EGC

Putri, F.K. (2016). Aktivitas Antioksidan dan Kualitas Teh Kombinasi Rambut Jagung dan Daun Kelor dengan Variasi Sugu Pengeringan. Skripsi.Universitas Muhammadiyah Surakarta.

Rafanani, B. (2013). Buku Pintar Pola Makan Sehat Dan Cerdas Bagi Penderita Diabetes. Yogyakarta: Araska

Ri, F. dan Wirawanni, Y. (2012). Asupan Energi, Karbohidrat, Serat, Beban Glikemik, Latihan Jasmani dan Kadar Gula Darah pada Pasien Diabetes Mellitus Tipe 2. Media Medika Indonesiana. 46(2). Tersdia dalam: http://www.ejournal.undip. ac.id/index.php/mmi/article/view/4273 
PROFESI (Profesional Islam): Media Publikasi Penelitian 2019; Volume 16; No 2. Website: ejournal.stikespku.ac.id

Sari, R.N. (2012). Diabetes Melitus. Yogyakarta: Nuha Medika

Setiati, S., Alwi, I., Sudoyo, A.W., Simadibrata, M., Setiyohadi, B., dan Syam, A.F. (2015). Buku Ajar Iilmu Penyakit Dalam. Jilid II. Ed VII. Jakarta: Interna Publishing.

Silverthorn, D.U. (2014). Fisiologi manusia sebuah pendekatan terintegrasi. Jakarta: EGC.

Simpus. (2016). Data Kunjungan Pasien Diabetes Di Puskesmas Paron.

Tjokroprawiro, A., Setiawan, P.B., Effendi, C., Santoso, D., dan Soegiarto, G. (2015). Buku Ajar Ilmu Penyakit Dalam. ed 2. Surabaya: Airlangga University Press

Upritchard, J.E., Sutherland, W.H., dan Mann, J.J. (2000). Effect of Supplementation With Tomato Juice, Vitamin E, and Vitamin C on LDL Oxidation and Products of Inflammatory Activity in Type 2 Diabetes. Diabetic care. 23(6): 723-738. doi: 10.2337/diacare.23.6.733
WHO. (2014). “Diabetes”. Diakses 8 Mei 2017.

WHO. (2016). "Global report on diabetes". Diakses 8 Mei 2017, tersedia dalam http://www. who.int/diabetes/publications/ grd-2016/en/

Wicaksono, P.R. (2011). Faktor-faktor yang berhubungan dengan diabetes melitus tipe 2. Skripsi, Fakultas Kedokteran: Universitas Diponegoro. E-Jorunal Undip. Tersedia dalam: http://eprints.undip.ac.id/ 37123/1/Radio_P.W.pdf

Wright, Mc, Bogdan. (2008). Panduan Bagi Penderita Diabetes. Jakarta: Prestasi Pustaka Publisher.

Zhao R, Li Q, Long L, Li J, Yang R, Gao D. (2007). Anti DM tipe 2 Antidiabetic activity of flavone from Ipomoea batatas leaf in non sulin dependent dependent diabetic rats. Int J Food Sci Tech. 42: 8085 . 